Vukašin Šušić 1

Dejan Ž. Đorđević

University of Nǐs

Faculty of Economics
ORIGINAL SCIENTIFIC ARTICLE doi:10.5937/ekonomika1902027S Received: April 08, 2019 Accepted: May, 08, 2019

\title{
MODERN TENDENCIES OF INTERNATIONAL TOURISM DEVELOPMENT
}

\begin{abstract}
Tourism is one of the most complex, most dynamic economic and socio spatial phenomena of the modern world, which has become a global phenomenon in a relatively short period of time (from the 1950s). This is best reflected in significant quantitative, qualitative, structural, spatial and other transformations both in the sphere of demand and in the sphere of supply. In the observed period, the volume of demand was constantly increasing, accompanied by the expansion of diverse motives and the needs of tourists for traveling, which led to the increasing heterogeneity and complexity of the emitting markets. At the same time, the supply market has been expanded so that almost every space on the earth has become available to modern tourists, even Antarctic.
\end{abstract}

Key words: international tourism, regional structure, turnover, revenues

JEL classification: F63, R11, Z32

\section{САВРЕМЕНЕ ТЕНДЕНЦИЈЕ РАЗВОЈА МЕЪУНАРОДНОГ ТУРИЗМА}

\begin{abstract}
Апстракт
Туризам је једна од најсложенијих, најкомплекснијих, најдинамичнијих економских и социопросторних појава савременог света који је у релативно кратком временском периоду (од 50-их година 20. века) постао глобални феномен. То се најбоље огледа у значајним квантитативним, квалитативним, структурним, просторним и другим трансформаџијама, како у сфери тражње, тако и у сфери понуде. У посматраном периоду перманентно се увећавао обим тражње праћен иирењем спектра мотива и потреба туриста за путоваьем, што је водило све већој хетерогености и сложености емитивних тржишта. Истовремено проширено је и тржиште понуде тако да је савременом туристи постао доступан готово сваки простор на земљи, па чак и Антартик.
\end{abstract}

Кључне речи: међународни туризам, регионална структура, промет, приходи

\footnotetext{
${ }^{1}$ vukasingeo@gmail.com

${ }^{2}$ ekngeo@gmail.com
} 


\section{Introduction}

The role of tourism in the global economy is enormous, which can best be seen through tourism traffic and revenues generated from international tourism. According to the data for 2017, the number of foreign arrivals was 1.326 million, and the realized revenues amounted to 1.340 million US \$. The main characteristic of modern tourism trends is mass. According to the World Tourism Organization, half (53\%) of all international arrivals are motivated by tourist reasons (vacation, recreation and other forms of leisure), business trips account for 14\%, while all other trips account for $27 \%$ (visit to relatives and friends, religious reasons and pilgrimages, medical treatments, etc.). The reason for traveling for about $6 \%$ of international travelers is unknown (UNWTO Tourism Highlights, 2015 Edition.).

However, international tourism trends represent a smaller part of an overall tourism trend in the world. Namely, according to estimates of the World Tourism Organization, the turnover of domestic tourists (tourist movements within the national territory) ranges from 5-6 billion a year. Tourism is a very important economic activity by turnover and income. Under modern conditions, direct revenues from travel and tourism reach 3-1\% of the world's GDP, and together with indirect and induced revenues they account for almost $10 \%$ of the world's GDP. Tourism revenues account for around $7 \%$ of the world's total exports and around 30\% of world trade in services. Concerning export, tourism is placed behind the export of energy products and chemical products, and in front of food and car exports. In many developing countries, tourism is the leading export sector. About 280 million or $9.4 \%$ of the total number of employees in the world are employed in tourism (World Travel \& Tourism Council, UNWTO org.).

\section{Factors of international tourism development}

The accelerated development of tourism since the 1950s has been influenced by numerous factors, among which are particularly emphasized: increasing living standards and free money, increasing leisure time and the number of travel motives, the process of urbanization that has increased the desire for a break, recovery, recreation, traffic development, especially automobile that contributed to the massiveness and mobility of tourists and air traffic, which enabled faster travel to the most distant destinations, the appearance of tour operators and organized trips enabled the most of the population to engage in tourist trips, relatively stable political situation in the world, the process of globalization, which increased the mobility of people, goods, services, investments, ideas and expanded the world tourism market, information and communication technologies that enhanced tourism business and interconnected societies, countries, institutions and individuals in new ways and suppressed the limiting effects of time and space (Marić, 1999; Wiliams 2008; Šušić, 2017).

In addition to the previously mentioned positive factors, there were also limiting factors that influenced the development of international tourism at the global, and more often at the regional level. The closure of Eastern European countries (former socialist countries), China and some other countries has negatively reflected on the growth rate and the direction of tourism trends in international tourism. The development of 
international tourism, especially in regional contexts, was influenced by political factors and wars of a local character (e.g. the Middle East region). The global economic crisis, such as the oil crisis in the mid-70s and the beginning of the $1980 \mathrm{~s}$, when many countries hit the economic recession, as well as the economic crisis in 2008 and the terrorist attack in 2001, did not slow down the growth of the international tourist traffic.

At the end of the $20^{\text {th }}$ and the beginning of the $21^{\text {st }}$ century, in the sublevel post Fordism, there are significant changes that are visible in the economy, politics, information technology, etc. The tendency of changing the industrial concept of tourism development is becoming more and more present, because the industrial way of life and work is transformed, according to which the development has been shaped. The level of education of tourists is increasing, and accordingly, there is a need for a different tourist product which implies the existence of numerous contents that include outdoor activities and awareness of environmental problems. Tourists become more demanding, more choosey and look for new forms of supply and new destinations to meet their new needs. This situation requires organizers of the trip to form new and more diverse travel programs and to develop a complex tourism product through the synchronized activity of the participants according to the tourist policy and the population. This "new" tourism is characterized by flexibility, segmentation and authentic tourist experience (Pasinović, 2006, p. 9). The development of qualitatively new tourism enables us to satisfy, above all, the requirements of modern demand for authenticity, experience in the local environment, as well as the demand of tourists for respecting the host (Todorović, Štetić, 2009).

So, at the end of the $20^{\text {th }}$ and the beginning of the $21^{\text {st }}$ century, tourists leave stable tourism movements and try to solve their needs in a different way. The basic characteristics of this new tourism are: reduction of mass tourism trends, search for new tourist products, more divers and active vacations, active involvement in the creation of a tourist product, segmentation of demand for specific products, breaks for complete relaxation of the spirit and the body, direct communication with the potential consumer, greater ecological awareness of tourists etc. (Todorović, Štetić, 2009; Šušić, 2017)

Changes are reflected in restructuring and moving towards new destinations. The participation of Asia and the Pacific, as well as the countries of Eastern Europe is increasing more in the tourism industry. Changes occurred in the time duration of the trip. There are more frequent journeys replacing long journeys. In addition, there are more and more new products in the offer of tour operators and other tourism companies which are adapted to the more complex demands of consumers. Tour operators of developed countries of the world are becoming complex systems, made of tour operators specializing in meeting the needs of a particular group of consumers. In this way, the diversity and quality of services has increased, and a more humane dimension is provided as well as the closer communication facilities between the participants in the tourist demand and supply. In the tourist offer, the development of tourism should be directed so that differences in the cultural level of the domicile population and tourists are complemented, and in the service itself to permeate the authenticity with the richness of modern production. In other words, the authenticity of the environment with the professionalism of services should be combined (Dulčić, Petrić, 2001).

New tourists are more experienced, more flexible, independent, and more aware of the quality of the tourist product and are more likely to meet the complete tourist needs. 
Quality and value for money are the main determinants of the tourism market. Modern tourists want to be different from the crowd (mass tourists) and look for an individualized tourist product. Individualization means optimizing the possibility of choosing the best solutions to meet your tourist needs. On the other hand, this implies that service providers in tourism (tourist agencies, hotels, etc.) must guarantee better quality, greater flexibility in attracting tourists and pay more attention to the psychophysical needs of a modern tourist (Weiermair, Steinhauser, 2003).

In addition, the development of environmental awareness of the threat of the natural environment leads to a new nature of tourism and essential changes in relation to the environment. For this new tourism, which is significantly different from the so-called "Mass tourism", there are other terms that are used such as "Soft tourism, Ecotourism, Sustainable Tourism, New Tourism, Responsible Tourism" and so on. (UNWTO, 2017)

Regardless of the previously mentioned factors, some of which are stimulating and the other restricting in the relation to the development of international tourism, it has been almost always an upward trend in the middle of the twentieth century. The exception is the aforementioned oil crisis, the economic crisis of 1997/98 in Southeast Asia and economic recession in 2008. The permanent growth of tourism is reflected in a growing number of countries that choose to do basic and additional business in tourism, to build the necessary infra and supra structures and to introduce various stimulating measures in tourism (Šušić, 2017).

The development of tourism, in addition to state economic policy and investments in tourism, has been influenced by multinational companies in the field of tourist mediation (tour operators, travel agencies) by hotel industry, and also by traffic (aircraft and cruise companies), which, thanks to the process of globalization, significantly penetrate and expand their business activity on once inaccessible national tourist markets (e.g. the market of China, Russia, etc.). The emergence of powerful companies in tourism has influenced not only qualitative-quantitative, but also spatial-geographical changes in tourism and tourism trends. (Čerović, 2002). This will affect the emergence of new, until then unknown, remote tourist destinations.

\section{Trends in traffic and revenues in international tourism}

The best indicators of the impressive development of international tourism are the increase in the number of tourists and tourism revenues in the period from 1950 to 2017. From 1950 to 2017, the number of arrivals in international tourism increased from 25.3 million to 1.340 million, i.e. over 50 times. Even more impressive is the increase in international tourism revenues, which increased 600 times, from 2.1 billion to 1.340 million US dollars (Table 1). Thus, with the exception of 1982, when the tourism turnover was down by $0.36 \%$, and tourism revenues by $6.1 \%$, as well as in 2009 , when the number of tourists decreased by $3.8 \%$ and revenues by $9.45 \%$ compared to the previous year, in the period from 1950 to 2017, there was a constant annual growth of international tourism.

It should be emphasized that tourism, in comparison with other segments of social and economic development, significantly overtook the effects of economic recession (Unković, Zečević, 2007). This statement is best confirmed by the oil crisis in the mid-1970s and the economic crisis in Southeast Asia in 1997/98, although slight growth of tourist traffic was 
recorded. However, factors that are outside the field of economics can also negatively affect tourism traffic. Judging by the annual rate of growth in the number of tourists and income, international tourism was developing rapidly in the period from 1950 to 1970. In this period, tourism has a massive character, which is reflected in the high average annual growth rate (growth rate of $10 \%$ of tourists and tourist income of $11.3 \%$ ). In this period, some countries, and especially the countries of Europe, have rapidly built the necessary tourist facilities and transport infrastructure, and with the appearance of tour operators and tourist arrangements, as well as appropriate propaganda contributed to the increase in the number of tourists (e.g. Spain, Italy, Greece, etc.) (Stankovic, 2000).

Table 1. Trends in tourist turnover and revenues in the World (1950-2017.)

\begin{tabular}{|c|c|c|}
\hline Year & Number of arrivals in M. & Revenues in M. US \$ \\
\hline 1950 & 25.3 & 2.1 \\
\hline 1960 & 69.3 & 6.9 \\
\hline 1970 & 159.7 & 17.4 \\
\hline 1980 & 284.4 & 102.4 \\
\hline 1990 & 434 & 255 \\
\hline 2000 & 677 & 476 \\
\hline 2010 & 948 & 931 \\
\hline 2017 & 1326 & 1340 \\
\hline
\end{tabular}

Source: UNWTO Tourism Highlights, 2000- 2018 Edition, Čerović, 2002

In the period 1970-1990, the tendency of the growth of international tourist traffic continued. However, the annual growth rate was lower than in the previous twenty-year period (1950-1970). This period was characterized by considerably faster increase of tourist consumption in relation to traffic of tourists. The higher growth rate of tourism revenues than the turnover of tourists was conditioned by the increase in the living standards of the population, especially in the underdeveloped countries of the world, as well as by the significant increase in the quality of catering services (Unković, Zečević, 2007). In this period, in addition to the new tourist destinations in the Mediterranean, in comparison with the most important emitting areas (Europe, North America, etc.), new distant destinations appear (countries of East and Southeast Asia, Mexico, island destinations in the Pacific, Indian and Atlantic oceans, etc.).

Table 2. Growth rates in international tourism (1950-2017)

\begin{tabular}{|c|c|c|}
\hline \multirow{2}{*}{ Period } & \multicolumn{2}{|c|}{ Annual growth rate in \% } \\
\cline { 2 - 3 } & arrivals & revenues \\
\hline $1950-1960$. & 10.6 & 12.6 \\
\hline $1960-1970$. & 9.1 & 10.1 \\
\hline $1970-1980$. & 5.7 & 19.4 \\
\hline $1980-1990$. & 4.8 & 9.7 \\
\hline $1990-2000$. & 4.3 & 7.7 \\
\hline $2000-2010$. & 3.4 & 5.5 \\
\hline $2010-2017$. & 5.1 & 5.4 \\
\hline
\end{tabular}

Source: UNWTO Tourism Highlights, 2000- 2018 Edition, Čerović, 2002.

Since 1990, further, but still slower growth in tourism arrivals and revenue in international tourism has continued. The processes of globalization, China's rapid economic 
opening, political and economic changes in former socialist countries have affected the spatial redistribution of tourism and international tourism revenues (e.g. Poland, the Czech Republic, Hungary, etc.). Turkey had a significant impact on the development of tourism in the Eastern Mediterranean. In addition, there are changes in the time duration of the trip, and long tourist travels are replaced by shorter and more frequent trips. Due to the development of informational telecommunication technologies, in the offer of tour operators and other tourism companies, new products appear to satisfy the more complex requirements of consumers. In this period, the development of international tourism, besides economic factors, was influenced by non-economic factors. Drastic cases, which led to a decline in the annual growth rates of international tourism in some years, are related to the aforementioned terrorist attack on September 11, 2001, and the economic recession of 2008. However, in the period from 2000-2010, the annual growth rate of tourists' turnover was $3.4 \%$, and revenues $5.5 \%$. War clashes, the unstable political situation in some countries and terrorist attacks have a significant impact on tourism in some parts of the world. The Arab Spring in 2011 influenced the decline in tourism in North Africa by $9.1 \%$ (e.g. Tunisia), and in the Middle East (e.g. Egypt, Jordan, etc.) by 8\%. In the period 2010-2017, the growth rate of tourists was $5.1 \%$ and revenues in international tourism $5.4 \%$.

\section{Regional structure of international tourism}

Based on the data given in Table 3, it can be concluded that the increase in the number of international travelers is evident in all regions of the world. Europe is still the dominant tourist region in the world, although its participation in the total number of foreign arrivals in the world is steadily decreasing.

In the international tourist traffic in 1970, Europe absorbed $3 / 4$ of all world movements of foreign tourists. From that period, its share in the total global turnover of foreign tourists has been steadily decreasing (from $60 \%$ in 1990 to $50 \%$ in 2017). At the same time, there was a spatial redistribution of international tourism trends in Europe in order to reduce participation in Western Europe's international tourist traffic from 24.9\% in 1990 to $14.4 \%$ in 2017 and to increase the participation of Central and Eastern Europe with $7.8 \%$ to $10.0 \%$. The participation of South Europe / the Mediterranean in the total international tourism turnover did not change significantly.

The most dynamic growth in international tourism since the 1970s has been in Asia and Australia. In the period 1970-1990, the share of this region in total international tourism increased from 3\% in 1970 to $12.8 \%$ in 1990. The accelerated economic development of East Asian countries, especially China, led to a further increase in foreign arrivals and a percentage share in world tourist traffic of $24.5 \%$ in 2017 . The number of tourists in Northeast and Southeast Asia during the period 1990 - 2017 increased by more than five times (the average for the world is about 3 times). At the same time, the share of America in the total international tourism turnover is steadily decreasing, in 1990 it was $21.3 \%$ and in 2017 it was $16.2 \%$. The largest decline in participation in international tourism in the observed period was recorded by North America (USA, Canada and Mexico) from 16.4\% to $10.3 \%$. In the same period, the participation of South America, Central America and Caribbean in international tourist traffic did not change significantly. 
Table 3. Traffic of tourists by tourist regions

\begin{tabular}{|c|c|c|c|c|c|c|c|c|}
\hline \multirow[t]{2}{*}{ Region } & \multicolumn{2}{|c|}{1990} & \multicolumn{2}{|c|}{2000} & \multicolumn{2}{|c|}{2010} & \multicolumn{2}{|c|}{2017} \\
\hline & M. & $\%$ & M. & $\%$ & M. & $\%$ & M. & $\%$ \\
\hline Europe & 261.5 & 60.1 & 385.6 & 57.1 & 489.4 & 51.5 & 671.7 & 50.1 \\
\hline N Europe & 28.6 & 6.6 & 43.7 & 6.5 & 62.8 & 6.6 & 77.8 & 5.6 \\
\hline W Europe & 108.6 & 24.9 & 139.7 & 20.7 & 154.4 & 16.3 & 192.7 & 14.4 \\
\hline $\mathrm{C}$ and E Europe & 33.9 & 7.8 & 69.3 & 10.2 & 98.9 & 10.4 & 133.7 & 10.0 \\
\hline $\begin{array}{l}\text { S Europe / } \\
\text { Mediterranean }\end{array}$ & 90.3 & 20.7 & 133.0 & 19.7 & 173.3 & 18.2 & 267.4 & 20.1 \\
\hline $\begin{array}{l}\text { Asia and the } \\
\text { Pacific }\end{array}$ & 55.8 & 12.8 & 110.1 & 16.3 & 205.5 & 21.6 & 279.2 & 24.3 \\
\hline SI Asia & 26.4 & 6.1 & 58.3 & 8.6 & 111.5 & 11.9 & 142.1 & 12.0 \\
\hline SI Asia & 21.2 & 4.9 & 36.1 & 5.3 & 70.5 & 7.4 & 104.6 & 7.7 \\
\hline Oceania & 5.2 & 1.2 & 9.6 & 1.4 & 11.4 & 1.2 & 14.2 & 1.2 \\
\hline S Asia & 3.1 & 0.7 & 6.1 & 0.9 & 12.1 & 1.3 & 18.3 & 2.0 \\
\hline America & 92.8 & 21.3 & 128.2 & 19.0 & 150.2 & 15.8 & 192.6 & 16.2 \\
\hline N America & 71.7 & 16.4 & 91.5 & 13.6 & 99.5 & 10.5 & 127.6 & 10.3 \\
\hline Caribbean & 11.4 & 2.6 & 17.1 & 2.5 & 19.5 & 2.0 & 23.9 & 2.0 \\
\hline C America & 1.9 & 0.4 & 4.3 & 0.6 & 7.9 & 0.7 & 10.3 & 1.0 \\
\hline S America & 7.7 & 1.8 & 15.3 & 2.3 & 23.2 & 2.4 & 30.8 & 2.9 \\
\hline Africa & 14.8 & 3.4 & 26.2 & 3.8 & 50.4 & 5.3 & 53.5 & 5.1 \\
\hline S. Africa & 8.4 & 1.9 & 10.2 & 1.5 & 19.7 & 2.1 & 18.0 & 1.8 \\
\hline $\begin{array}{l}\text { Subsahar. } \\
\text { Africa }\end{array}$ & 6.4 & 1.5 & 16.0 & 2.3 & 30.7 & 3.2 & 35.4 & 3.3 \\
\hline Near East & 9.6 & 2.2 & 24.1 & 3.4 & 54.7 & 5.7 & 53.3 & 4.3 \\
\hline THE WORLD & 435 & 100 & 674 & 100 & 950 & 100 & 1326 & 100 \\
\hline
\end{tabular}

Source: UNWTO Tourism Highlights, 2000- 2018 Edition

The African continent participated in international tourist traffic in 2017 with $5.1 \%$, which is less than in 2010, when the share was 5.3\%. The decline in tourism, especially in North Africa, is a result of reduced security of tourists due to threats from terrorist attacks. (e.g. terrorist attack on hotels in Tunisia in June 2015). By the year 2010, the region of the Middle East had had a permanent increase in participation in international tourism (from 2.2\% in 1990 to $5.7 \%$ in 2010). Due to the aforementioned "Arab spring", terrorist attacks in 2015, as well as the war in Syria, participation in international tourism has been reduced to $4.3 \%$.

\section{The emitting and receptive countries of the World}

The division of countries into emitting and receptive regions of the world is conditional, although the countries of the first category are highly developed and the main generators of demand and the middle-developed and undeveloped countries are the main generators of the offer (Čomić, Singer, 1997). But this is not always the case, because some emitting countries are at the same time regions with significant tourist offer (France, Great Britain, Germany, USA, Switzerland, etc.). Many undeveloped 
countries that have favorable conditions for the development of international tourism are geographically very distant from the most important emitting areas and directions. This distance has a relatively large impact on the development of tourism, which is primarily intended for clients with higher payment possibilities (numerous exotic islands in the Pacific, Atlantic and Indian Ocean).

According to consumption in 2000, the most important emitting areas are related to the economically most powerful and most developed countries in the world. The first ten countries generated around $55 \%$ of the total consumption in international tourism in the year. The most important emitting countries were the USA, Germany, Great Britain, Japan and France and others.

Table 4. The most important emitting countries of the world in terms of consumption in international tourism in 2000 and 2016

\begin{tabular}{|c|l|c|c|c|l|c|c|}
\hline \multicolumn{9}{|c|}{2000} & \multicolumn{4}{c|}{2016} \\
\hline Number & \multicolumn{1}{|c|}{ Country } & In M. & $\begin{array}{c}\text { \% in the } \\
\text { World }\end{array}$ & Number & Country & In M. & $\begin{array}{c}\text { \% in the } \\
\text { World }\end{array}$ \\
\hline 1 & USA & 64.5 & 13.7 & 1 & China & 261.1 & 19.5 \\
\hline 2 & Germany & 47.6 & 10.0 & 2 & USA & 123.6 & 9.2 \\
\hline 3 & G. Britain & 36.6 & 7.7 & 3 & Germany & 79.8 & 5.9 \\
\hline 4 & Japan & 31.5 & 6.6 & 4 & G. Britain & 63.6 & 4.7 \\
\hline 5 & France & 17.2 & 3.6 & 5 & France & 45.5 & 3.4 \\
\hline 6. & Italy & 15.5 & 3.2 & 6. & Canada & 29.1 & 2.2 \\
\hline 7 & China & 13.1 & 2.9 & 7 & J. Korea & 26.6 & 2.1 \\
\hline 8 & Hong Kong & 12.5 & 2.7 & 8 & Italy & 25.0 & 1.9 \\
\hline 9 & Netherlands & 12.2 & 2.6 & 9 & Australia & 24.9 & 1.9 \\
\hline 10 & Canada & 12.1 & 2.5 & 10 & Hong Kong & 24.2 & 1.8 \\
\hline
\end{tabular}

Source: UNWTO Tourism Highlights, 2000- 2017 Edition

In the period 2010-2016 there were significant changes in the order of the list of the most important emitting countries. Since 2003, China has a two-digit annual growth rate of consumption, which has contributed to becoming the world's leading emitting state. In 2016, this country accounted for nearly $20 \%$ of consumption in international tourism. South Korea and Australia emerged as new large emitting areas. Residents of the ten most important emitting countries spent $\$ 703$ billion in 2016, accounting for $53 \%$ of total international tourism spending. Besides these already mentioned countries, Spain, Sweden, the Netherlands, Taiwan and others are among the most important emitting countries.

Table 5. Leading receptive states of the world according to tourist traffic

\begin{tabular}{|c|l|c|c|c|c|c|c|}
\hline \multicolumn{3}{|c|}{2000} & \multicolumn{4}{c|}{2016} \\
\hline Number & \multicolumn{1}{|c|}{ Country } & In M. & $\begin{array}{c}\text { \% in the } \\
\text { World }\end{array}$ & Number & Country & In M. & $\begin{array}{c}\text { \% in the } \\
\text { World }\end{array}$ \\
\hline 1 & France & 75.5 & 10.8 & 1 & France & 82.6 & 7.2 \\
\hline 2 & USA & 50.9 & 7.3 & 2 & USA & 75.6 & 6.5 \\
\hline 3 & Spain & 48.2 & 6.9 & 3 & Spain & 75.6 & 5.8 \\
\hline
\end{tabular}




\begin{tabular}{|c|l|c|c|c|l|c|c|}
\hline 4 & Italy & 41.2 & 5.9 & 4 & China & 59.3 & 4.8 \\
\hline 5 & China & 31.2 & 4.5 & 5 & Italy & 52.4 & 4.3 \\
\hline 6. & G. Britain & 25.2 & 3.6 & 6. & G. Britain & 35.8 & 3.3 \\
\hline 7 & Russia & 21.2 & 3.0 & 7 & Germany & 35.6 & 3.0 \\
\hline 8 & Mexico & 20.6 & 3.0 & 8 & Mexico & 35.0 & 2.9 \\
\hline 9 & Canada & 20.4 & 2.9 & 9 & Thailand & 32.6 & 2.7 \\
\hline 10 & Germany & 19.0 & 2.7 & 10 & Turkey & - & - \\
\hline
\end{tabular}

Source: UNWTO Tourism Highlights, 2001- 2017 Edition

In order to determine the most important tourist destinations of international tourism, the number of international arrivals and revenues in international tourism is taken as a key indicator. From the tables, it is noted that the most commonly developed countries of the world are at the same time the most important tourist destinations. Tourist business of these countries is influenced by numerous business trips, urban and cultural tourism. China joined this circle of receptive countries (opening up to the world and accelerated industrial development) in the 1990s, and Russia, in 2002, thanks to significant investments in the necessary touristic supra structure, and Turkey.

The US, China, Spain, France, G. Britain and others have the greatest revenue. The United States, with a convincing first place in terms of revenues from international tourism, accounted for 205 billion US \$ and participation in international tourism revenues of $15.4 \%$, while the other is Spain with revenues of $4.5 \%$. It should be noted that China with Hong Kong and Macao has revenues from international tourism of over 100 billion US \$.

Table 6. Most important receptive states according to tourism revenues

\begin{tabular}{|c|l|c|c|c|l|c|c|}
\hline \multicolumn{4}{|c|}{2000} & \multicolumn{4}{c|}{2016} \\
\hline Number & Country & $\begin{array}{c}\text { billion \$ } \\
\text { US }\end{array}$ & $\begin{array}{c}\text { \% in the } \\
\text { World }\end{array}$ & Number & Country & $\begin{array}{c}\text { billion \$ } \\
\text { US }\end{array}$ & $\begin{array}{c}\text { \% in the } \\
\text { World }\end{array}$ \\
\hline 1 & USA & 85.2 & 17.9 & 1 & USA & 205.9 & 15.4 \\
\hline 2 & Spain & 31.0 & 6.5 & 2 & Spain & 60.3 & 4.5 \\
\hline 3 & France & 29.9 & 6.3 & 3 & Thailand & 44.9 & 3.4 \\
\hline 4 & Italy & 27.4 & 5.8 & 4 & China & 44.4 & 3.3 \\
\hline 5 & G. Britain & 19.5 & 4.1 & 5 & France & 42.5 & 3.2 \\
\hline 6. & Germany & 17.8 & 3.7 & 6. & Italy & 40.2 & 3.0 \\
\hline 7 & China & 16.2 & 3.4 & 7 & G. Britain & 39.6 & 2.9 \\
\hline 8 & Austria & 11.4 & 2.4 & 8 & Germany & 37.4 & 2.8 \\
\hline 9 & Canada & 10.8 & 2.3 & 9 & Hong Kong & 32.9 & 2.5 \\
\hline 10 & Greece & 10.8 & 1.9 & 10 & Australia & 32.4 & 2.5 \\
\hline
\end{tabular}

Source: UNWTO Tourism Highlights, 2001- 2015 Edition

As a rule, tourist destinations that are closer to more important emitting areas have higher tourist traffic. The best examples are the countries of the Mediterranean located near the large emitting regions of Western, Central and Northern Europe. It is similar to Mexico and many Caribbean states located near one of the largest emitting areas such as the United States. With the collapse of the socialist bloc and the opening of China since the 1990s, all important tourist flows have been directed towards these countries. At the same time, with 
the rise of the living standards of the countries of these regions, they become an emission area, whose population is increasingly traveling towards affirmed tourist destinations in Europe, the Middle East and North Africa, and the Caribbean islands.

\section{Conclusion}

The question of the future development of tourism in the world is justifiably asked. Some projections are based on the assumption that the future development will follow the trends of the previous period of tourism development in which mass tourism had the dominant role. Other hypotheses are based on changing the way of life in post-industrial society, the increasing use of information and communication technology, the emergence of new tourist needs, non-standardized tourist services and new forms of tourism that will be created by tourists themselves.

Trends foreseen by the World Tourism Organization take into account factors that limit or encourage tourism development. It identifies external and internal factors that influence the development of tourism. External factors include: economic and financial development, demographic and social changes, communication and information technologies, travel and stay safety in the destination, political factors, environmental pollution, natural disasters, climate change, other extreme changes in nature, etc. Internal factors include: changes in tourist demand, changes in tourist offer, changes in distribution channels, changes in tourism products and services, etc. (Gee, Fayos-Sola, 1997).

According to experts of the World Tourism Organization, further growth of tourism traffic in all spatial units in the World is foreseen. The turnover of tourists in international tourism in 2030 will amount to 1.809 million (UNWTO, 2011). In the future, there will be a change in the spatial distribution of tourism in the world. The dynamics of the growth of international tourism in Europe and America will be slower than in other major tourist regions of the world, such as East Asia, the Pacific, Africa, and so on.

\section{References}

Čerović, S. (2002). Strategijski menadžment turističke privrede Srbije. Želind, Beograd.

Čomić, Đ., Pjevač, N. (1997). Turistička geografija, Beograd.

Gee, CY, \& Fayos-Sola, E. (1997). International tourism: A Global Perspektive. Madrid, World Tourism Organization

Dulčić, A., \& Petrić, L. (2001). Upravljanje razvojem turizma. Zagreb, Mate.

Economic impact 2015 World, World Travel \& Tourism Council (WTTC), https:// www.wttc.org/-/media/files/reports/world2015.pdf

Marić, R. (1999). Savremene tendencije u međunarodnom turizmu. Turizam br.3, Naučnostručni časopis iz oblasti turizma, Novi Sad: Institut za geografiju PMF Novi Sad,.

Ministarstvo trgovine i turizma Republike Srbije (2005). Strategija turizma Republike Srbije. Beograd. 
Pasinović, M. (2006). Menadžment prirodnih i kulturnih resursa. Fakultet za turizam, hotelijerstvo i trgovinu, Bar.

Recommendations on Tourism Statistics, (2010). United Nations Department for Statistical Division and World Tourism Organization (1994). Economic and Social Information and Policy Analysis. Statistical Papers, Series M, No. 83 United Nations, New York.

Stanković, S. (2000). Turistička geografija. Peto dopunjeno izdanje, Beograd, A.M.I.R.

Šušić, V. (2017). Turistička geografija. Niš, Ekonomski fakultet.

Todorović, M., \& Štetić, S. (2009). Ruralni turizam. Beograd, Univerzitet u Beogradu, Geografski fakultet.

Unković, S., \& Zečevič, J. (2007). Ekonomika turizma. Beograd, Centar za izdavačku delatnost Ekonomskog fakulteta u Beogradu.

UNWTO (2011). Tourism Towards 2030 Advance Edition: Key Results. 5th UNWTOPATA Forum on Tourism Trends and OutlookGuilin, China, 27 October 2011.

UNWTO Tourism Highlights, 2001 Edition, Madrid, World Tourism Organization,

UNWTO Tourism Highlights, 2015 Edition, Madrid, World Tourism Organization

UNWTO Tourism Highlights, 2017 Edition, Madrid, World Tourism Organization

UNWTO Tourism Highlights, 2018 Edition, Madrid, World Tourism Organization

UNWTO 2017, Annual Report, Madrid: World Tourism Organization

Williams, S., (2008). Tourism Geography: A new synthesis. London and New Jork, Routledge

Weiermair, K., Steinhauser, C., (2003). New tourism clusters in the field of sports and health; the case of Alpine wellness. Barcelona, 12th International Tourism and Leisure Symposium 